\title{
Kontrol Optimal pada Model Economic Order Quantity dengan Inisiatif Tim Penjualan
}

\author{
Abdul Latif Al Fauzi ${ }^{*}$, Isnani Darti ${ }^{1}$, Agus Suryanto ${ }^{1}$
}

\begin{abstract}
Economic order quantity (EOQ) is the order quantity of inventory that minimizes the total cost of inventory management. In this article we discuss the optimal control in the EOQ model with salesmen's initiatives not only at the equilibrium conditions, but also the optimal control with salesmen's initiatives at any time. The aim of optimal control is to minimize the total inventory costs, purchasing costs, selling price and cost of the effort of sales staff. By applying the Pontryagin Minimum Principle, it can be obtained optimal control condition. Numerical solution is solved by using sweep forward backward method to show the effect of the controls. Optimal control problem is solved using Pontryagin maximum principle, and numerically simulated using the Sweep Forward-Backward method. Numerical simulations show that the greater the level of demand coefficients, the faster the inventory level will be reduced. Furthermore, the more work the sales team so the process will be less inventory even faster.
\end{abstract}

Keywords: Optimal control, EOQ model, Pontryagin maximum, sweep forward-backward.

\section{Pendahuluan}

Pengendalian persediaan merupakan usaha-usaha yang dilakukan oleh suatu perusahaan termasuk keputusan-keputusan yang diambil sehingga kebutuhan akan bahan untuk keperluan proses produksi dapat terpenuhi secara optimal dengan resiko yang sekecil mungkin. Pengendalian persediaan barang memainkan peran utama dalam suatu sistem produksi dan merupakan faktor penting di antara sekian banyak faktor penting yang berkontribusi terhadap pengurangan biaya (Dhaiban [1]). Pengendalian persediaan barang merupakan salah satu masalah yang sering dihadapi oleh suatu perusahaan, karena sejumlah barang sangat diharapkan dapat diperoleh pada tempat dan waktu yang tepat, dengan ongkos yang murah. Selain itu, pengendalian persediaan barang juga dapat menekan biaya produksi, biaya pemesanan dan biaya penyimpanan menjadi seminimal mungkin (Muckstadt dan Sapra $[2])$.

Upaya pengendalian persediaan barang dapat dilakukan melalui beberapa cara, salah satunya melalui pemodelan matematika. Beberapa model matematika tentang persediaan barang adalah model EOQ (Economic Order Quantity), model EPQ (Economic Production Quantity) dan model EOI (Economic Order Interval). Salah satu model matematika tentang persediaan barang yang sering digunakan adalah model EOQ (Economic Order Quantity).

\footnotetext{
1 Fakultas Matematik dan Ilmu Pengetahuan Alam, Jurusan Matematika, Universitas Brawijaya, Jl. Veteran Malang, 65145, Email: yulialfauzi@gmail.com, isnanidarti@ub.ac.id, suryanto@ub.ac.id

* Penulis korespondensi
}

Model persediaan EOQ adalah suatu model tentang pengadaan atau persediaan bahan baku pada suatu perusahaan. Asumsi dasar dalam menerapkan metode EOQ adalah permintaan dapat ditentukan secara pasti dan konstan, item yang dipesan tidak bergantung kepada item yang lain, pesanan yang diterima dengan segera dan pasti, tidak terjadi stock out serta harga item konstan. Model ini dapat digunakan untuk menentukan jumlah pesanan yang memenuhi total biaya penyimpanan, sehingga tidak ada kekurangan persediaan (Kostic [3]). Penelitian tentang model EOQ sudah banyak dilakukan, diantaranya Baker dan Urban [4] membahas model persediaan dengan memperhatikan tingkat persediaan bergantung pada tingkat permintaan, Datta dan Pal [5] mengembangkan model tersebut dengan mempertimbangkan tingkat permintaan ketika barang-barang habis dimana faktor-faktor lain diasumsikan konstan, Ghosh dan Chaudhuri [6] mengembangkan model persediaan dengan dua tingkat penyimpanan, sedangkan Husniah dan Supriatna [7] mengkaji tentang model dinamik dari tingkat persediaan tiga jenis produk yang dijual secara bersamaan oleh sebuah tim pemasaran.

Model EOQ dapat dianalisis melalui pendekatan sistem dinamik, diantaranya Sana [8] yang membahas tentang analisis dinamik dan kontrol optimal model persediaan yang dipengaruhi inisiatif tim penjualan bersama untuk dua produk yang serupa. Sana [9] menambahkan harga produk pada model EOQ. Pada penelitian selanjutnya, Sana [10] mengembangkan analisis dinamik dan kontrol optimal model persediaan untuk produk yang serupa, tetapi dengan mengasumsikan bahwa kapasitas produksi terbatas dan permintaan barang tergantung pada tingkat pengadaan barang, serta 
inisiatif tim penjualan pada masing-masing produk secara terpisah. Anggraini et al. [11] juga membahas analisis dinamik dan kontrol optimal pada model pengendalian persedian dua produk berbeda dengan kapasitas produksi terbatas serta inisiatif tim penjualan bersama. Penelitian tentang model EOQ tersebut membahas kontrol optimal dengan inisiatif tim penjualan hanya pada saat kondisi setimbang saja, sehingga diperoleh kesetimbangan optimal.

Berbeda dengan penelitian sebelumnya, pada artikel ini akan dikaji tentang kontrol optimal dengan inisiatif tim penjualan tidak hanya pada saat kondisi setimbang saja, tetapi kontrol optimal dengan usaha tim penjualan pada setiap saat. Dalam hal ini diasumsikan bahwa kapasitas produksi terbatas dan permintaan barang tergantung pada tingkat pengadaan barang dan inisiatif tim penjualan pada masing-masing produk secara terpisah. Strategi kontrol optimal dilakukan dengan meminimumkan biaya persediaan, biaya pembelian, biaya penjualan dan biaya usaha tim penjualan. Masalah kontrol optimal diselesaikan menggunakan prinsip maksimum Pontryagin. Solusi optimal yang diperoleh disimulasikan secara numerik menggunakan metode Sweep Maju-Mundur dengan bantuan software MATLAB.

\section{Metode Penelitian}

Model kontrol optimal yang dikaji pada artikel ini merupakan model yang dikemukakan oleh Sana [10] dengan mengasumsikan bahwa kapasitas produksi terbatas dan permintaan barang tergantung pada tingkat pengadaan barang dan inisiatif tim penjualan pada masing-masing produk secara terpisah, yang dinyatakan dalam bentuk sistem persamaan diferensial berikut:

$\frac{d X}{d t}=r_{1}\left[1-\frac{X}{L_{1}}\right] X-\frac{C_{1} E_{1} X\left(1-\frac{Y}{L}\right)}{I_{11} E_{1}+I_{12} X}$

$\frac{d Y}{d t}=r_{2}\left[1-\frac{Y}{L_{2}}\right] Y-\frac{C_{2} E_{2} Y\left(1-\frac{X}{L}\right)}{I_{21} E_{2}+I_{22} Y}$

dengan $X$ menyatakan persediaan barang 1 yang ada pada waktu $t$ dan $Y$ menyatakan persediaan barang 2 yang ada pada waktu $t$. Tingkat pengadaan barang dinyatakan sebagai model logistik, dimana $r_{1}$ dan $r_{2}$ masing-masing menyatakan laju intrinsik pengadaan barang 1 dan laju intrinsik pengadaan barang 2 . Kapasitas maksimum penyimpanan barang 1 yang dapat ditampung gudang dinyatakan dengan $L_{1}$, sedangkan kapasitas maksimum penyimpanan barang 2 dinyatakan dengan $L_{2}$. Fungsi usaha bersama tim penjualan untuk barang 1 pada waktu $t$ dan untuk barang 2 pada waktu 2 masing-masing dinyatakan sebagai $E_{1}$ dan $E_{2}$. Selanjutnya, $C_{1}, C_{2}, l_{11}, l_{12}, l_{21}$ dan $l_{22}$ adalah koefi- sien positif dari tingkat permintaan barang 1 dan 2 . Parameter $l_{11}$ dan $l_{21}$ sebanding dengan rasio tingkat persediaan barang terhadap tingkat permintaan pada tingkat inisiatif tim penjualan yang lebih tinggi, sedangkan $l_{12}$ dan $l_{21}$ sebanding dengan rasio tingkat usaha terhadap tingkat permintaan pada tingkat persediaan yang lebih tinggi.

Fungsi yang menyatakan keuntungan yang diperoleh dari model EOQ ini adalah hasil penjualan barang 1 dan hasil penjualan barang 2, kemudian dikurangi biaya persediaan barang 1 , biaya persediaan barang 2 , dan biaya usaha tim penjualan. Secara umum, fungsi keuntungan tersebut dapat dituliskan sebagai berikut

$$
\begin{aligned}
\pi\left(X, Y, E_{1}, E_{2}\right)= & \left(s_{1}-p_{1}\right)\left[\frac{c_{1} E_{1} X\left(1-\frac{Y}{L}\right)}{I_{11} E_{1}+I_{12} X}\right]+ \\
& \left(s_{2}-p_{2}\right)\left[\frac{C_{2} E_{2} Y\left(1-\frac{X}{L}\right)}{I_{21} E_{2}+I_{22} Y}\right]- \\
& h_{1} X-h_{2} Y-\gamma_{1} E_{1}-\gamma_{2} E_{2}
\end{aligned}
$$

dengan

$h_{1}=p_{1} b+\frac{g_{1}}{X}+\alpha_{1} X$,

$h_{2}=p_{2} b+\frac{g_{2}}{Y}+\alpha_{2} Y$,

dengan $s_{1}, s_{2}, p_{1}$ dan $p_{2}$ masing-masing menyatakan biaya penjualan per unit barang 1 , biaya penjualan per unit barang 2 , biaya pembelian per unit barang 1, dan biaya pembelian per unit barang 2 .

Tujuan kontrol optimal pada artikel ini adalah memaksimumkan fungsi keuntungan $(\pi)$ yang mempertimbangkan biaya persediaan, biaya pembelian, biaya untuk usaha tim penjualan. Masalah kontrol optimal dari kasus ini adalah memaksimumkan fungsi tujuan yang dapat dinyatakan sebagai berikut:

$J\left(E_{1}, E_{2}\right)=\int_{0}^{T} \pi\left(X, Y, E_{1}, E_{2}\right) e^{-\delta t} d t$

dengan

$\delta=$ tingkat $\operatorname{bunga}(r)$ - tingkat inflasi $(b)$.

Masalah kontrol optimal pada model EOQ ini diselesaikan menggunakan prinsip maksimum Pontryagin [6]. Langkah awal untuk menyelesaikan masalah kontrol optimal menggunakan prinsip maksimum Pontryagin adalah terlebih dahulu dibentuk fungsi Hamilton sebagai berikut:

$$
\begin{aligned}
H= & \pi\left(X, Y, E_{1}, E_{2}\right) e^{-\delta t}+ \\
& \sum_{i=1}^{2} \sigma_{i}(t) f_{i}\left(X, Y, E_{1}, E_{2}\right) .
\end{aligned}
$$

dengan kondisi batas transversal

$\sigma_{i}(T)=0, i=1,2$.

Variabel kontrolnya adalah $\left(E_{1}, E_{2}\right)$ dan kendalanya $(0,0) \leq\left(E_{1}, E_{2}\right) \leq\left(E_{1}^{\max }, E_{2}^{\text {max }}\right)$ dengan $\left(E_{1}^{\max }, E_{2}^{\max }\right)$ merupakan batas atas usaha tim penjualan barang 
1 dan 2. Variabel state pada masalah ini adalah persamaan (1) dan (2), sedangkan variabel adjoint yang bersesuaian untuk variabel state dinyatakan sebagai $\sigma_{1}$ dan $\sigma_{2}$.

Berdasarkan prinsip maksimum Pontryagin, fungsi Hamilton mencapai solusi optimal jika persamaan state, persamaan costate, dan kondisi stasioner terpenuhi. Persamaan state untuk masalah kontrol optimal (3) dengan kendala (1)-(2) dan fungsi Hamilton (5) sebagai berikut:

$\frac{\partial H}{\partial \sigma_{1}}=\frac{d X}{d t}=f_{1}\left(X, Y, E_{1}, E_{2}\right)$,

$\frac{\partial H}{\partial \sigma_{2}}=\frac{d Y}{d t}=f_{2}\left(X, Y, E_{1}, E_{2}\right)$.

dengan kondisi awal $X(0)=X_{0}, Y(0)=Y_{0}$.

Persamaan costate (adjoint) ditentukan dengan menggunakan nilai negatif dari turunan fungsi Hamilton (5) terhadap masing-masing variabel state, sehingga diperoleh persamaan sebagai berikut:

$$
\begin{aligned}
\frac{\partial \sigma_{1}}{\partial t}= & -\frac{\partial H}{\partial X}= \\
& -\left[B_{7}-\frac{\left(s_{2}-p_{2}\right) C_{2} E_{2} Y}{\left(I_{21} E_{2}+I_{22} Y\right) L}-\left(p_{1} b+2 \alpha_{1} X\right)\right] e^{-\delta t} \\
& -\sigma_{1}\left[r_{1}\left[1-\frac{2 X}{L_{1}}\right]-\frac{C_{1} I_{11} E_{1}{ }^{2}\left(1-\frac{Y}{L}\right)}{\left(I_{11} E_{1}+I_{12} X\right)^{2}}\right] \\
& -\sigma_{2}\left[\frac{C_{2} E_{2} Y}{\left(I_{21} E_{2}+I_{22} Y\right) L}\right] .
\end{aligned}
$$

dengan

$$
B_{7}=\frac{\left(s_{1}-p_{1}\right) C_{1} I_{11} E_{1}^{2}(L-Y)}{L\left(I_{11} E_{1}+I_{12} X\right)^{2}},
$$

dan

$$
\begin{aligned}
& \frac{\partial \sigma_{2}}{\partial t}=-\frac{\partial H}{\partial Y}= \\
& -\left[\frac{-\left(s_{1}-p_{1}\right) C_{1} E_{1} X}{\left(I_{11} E_{1}+I_{12} X\right) L}+\frac{\left(s_{2}-p_{2}\right) C_{2} I_{2} E_{2}{ }^{2}(L-X)}{L\left(I_{21} E_{2}+I_{22} Y\right)^{2}}-D_{10}\right] e^{-\delta t} \\
& -\sigma_{1}\left[\frac{C_{1} E_{1} X}{\left(I_{11} E_{1}+I_{12} X\right) L}\right]-\sigma_{2}\left[r_{2}\left[1-\frac{2 Y}{L_{2}}\right]-\frac{C_{2} I_{21} E_{2}{ }^{2}(L-X)}{L\left(I_{21} E_{2}+I_{22} Y\right)^{2}}\right]
\end{aligned}
$$

dengan

$D_{10}=\left(p_{2} b+2 \alpha_{2} Y\right)$.

Selanjutnya ditentukan kondisi $\left(E_{1}, E_{2}\right)$ yang membuat sistem optimal. Kondisi optimal diperoleh ketika fungsi Hamilton memenuhi kondisi stasioner, yaitu

$\frac{\partial H}{\partial E_{k}}=0, \forall E_{k}, k=1,2$.

Adapun turunan parsial fungsi Hamilton terhadap masing-masing variabel kontrol adalah sebagai berikut

$$
\begin{aligned}
\frac{\partial H}{\partial E_{1}}= & {\left[\frac{\left(s_{1}-p_{1}\right) C_{1} I_{12} X^{2}(L-Y)}{L\left(I_{11} E_{1}+I_{12} X\right)^{2}}-\gamma_{1}\right] e^{-\delta t}-} \\
& \sigma_{1} \frac{C_{1} I_{12} X^{2}(L-Y)}{L\left(I_{11} E_{1}+I_{12} X\right)^{2}} .
\end{aligned}
$$

dan

$$
\begin{aligned}
\frac{\partial H}{\partial E_{2}}= & {\left[\frac{\left(s_{2}-p_{2}\right) C_{2} I_{22} Y^{2}(L-X)}{L\left(I_{21} E_{2}+I_{22} Y\right)^{2}}-\gamma_{2}\right] e^{-\delta t}-} \\
& \sigma_{2} \frac{C_{2} I_{22} Y^{2}(L-X)}{L\left(I_{21} E_{2}+I_{22} Y\right)^{2}}
\end{aligned}
$$

Kondisi stasioner dipenuhi jika memenuhi $\frac{\partial H}{\partial E_{k}}=0$, $\forall E_{k}, k=1,2 .(13)$

Berdasarkan kondisi stasioner pada persamaan (13) terhadap persamaan (11) dan persamaan (12), dapat ditentukan kondisi $E_{1}^{*}$ dan $E_{2}^{*}$ agar diperoleh sistem optimal;

$E_{1}^{*}=\frac{-A_{2} \pm \sqrt{A_{2}^{2}-4 A_{1} A_{3}}}{2 A_{1}}$,

dengan

$A_{1}=I_{11}^{2} L \gamma_{1} e^{-\delta t}$,

$A_{2}=2 I_{11} I_{12} X L \gamma_{1} e^{-\delta t}$,

$A_{3}=I_{12}{ }^{2} X^{2} L \gamma_{1} e^{-\delta t}-\left(s_{1}-p_{1}\right) C_{1} I_{12} X^{2}(L-Y) e^{-\delta t}$ $+\sigma_{1} C_{1} I_{12} X^{2}(L-Y)$,

dan

$E_{2}^{*}=\frac{-B_{2} \pm \sqrt{B_{2}{ }^{2}-4 B_{1} B_{3}}}{2 B_{1}}$,

dengan

$B_{1}=I_{21}{ }^{2} L \gamma_{2} e^{-\delta t}$,

$B_{2}=2 I_{21} I_{22} Y L \gamma_{2} e^{-\delta t}$,

$B_{3}=I_{22}{ }^{2} Y^{2} L \gamma_{2} e^{-\delta t}-\left(s_{2}-p_{2}\right) C_{2} I_{22} Y^{2}(L-X) e^{-\delta t}$ $+\sigma_{2} C_{2} I_{22} Y^{2}(L-X)$.

Oleh karena $0 \leq E_{k} \leq E_{\max }$ untuk $k=1,2$, diperoleh nilai kondisi optimal sebagai berikut:

$E_{k}^{*}=\left\{\begin{array}{lr}0, & E_{k}^{*}<0 \\ E_{k}^{*}, & 0 \leq E_{k}^{*} \leq E_{\max } \\ E_{\text {max }}, & E_{k}^{*}>E_{\max }\end{array}\right.$

Berdasarkan persamaan (14)-(16), nilai $E_{1}^{*}$ dan $E_{2}^{*}$ dapat dinyatakan sebagai:

$E_{1}^{*}=\min \left\{\max \left(0, \frac{-A_{2}+\sqrt{A_{2}^{2}-4 A_{1} A_{3}}}{2 A_{1}}, 1\right)\right\}$,

$E_{2}^{*}=\min \left\{\max \left(0, \frac{-B_{2}+\sqrt{B_{2}{ }^{2}-4 B_{1} B_{3}}}{2 B_{1}}, 1\right)\right\}$,

dengan

$A_{2}{ }^{2}-4 A_{1} A_{3}>0, A_{3}<0$, dan ${B_{2}}^{2}-4 B_{1} B_{3}>0, B_{3}<0$.

Misalkan $X^{*}$ dan $Y^{*}$ adalah kondisi state optimal dan $\sigma_{1}^{*}$ dan $\sigma_{2}^{*}$ adalah kondisi variabel adjoint yang bersesuaian. Kondisi optimal diperoleh dengan menyelesaikan sistem sebagai berikut:

$\begin{aligned} \frac{d X^{*}}{d t} & =f_{1}\left(X^{*}, Y^{*}, E_{1}^{*}, E_{2}^{*}\right), \\ \frac{d Y^{*}}{d t} & =f_{2}\left(X^{*}, Y^{*}, E_{1}^{*}, E_{2}^{*}\right) .\end{aligned}$ 
Variabel adjoint $\left(\sigma_{1}^{*}\right)$ dinyatakan sebagai

$$
\begin{aligned}
\frac{\partial \sigma_{1}^{*}}{\partial t}= & -\left[H_{1}-\left(s_{2}-p_{2}\right) \frac{C_{2} E_{2}^{*} Y^{*}}{\left(I_{21} E_{2}^{*}+I_{22} Y^{*}\right) L}-\left(p_{1} b+\right.\right. \\
& \left.\left.2 \alpha_{1} X^{*}\right)\right] e^{-\delta t}-\sigma_{1}\left[r_{1}\left[1-\frac{2 X^{*}}{L}\right]-\frac{C_{1} I_{11} E_{1}^{*}\left(1-\frac{Y^{*}}{L}\right)}{\left(I_{11} E_{1}^{*}+I_{12} X^{*}\right)^{2}}\right] \\
& -\sigma_{2}\left[\frac{C_{2} E_{2}^{*} Y^{*}}{\left(I_{21} E_{2}^{*}+I_{22} Y^{*}\right) L}\right],
\end{aligned}
$$

dengan

$H_{1}=\left(s_{1}-p_{1}\right) \frac{C_{1} I_{11} E_{1}^{* 2}\left(1-\frac{Y^{*}}{L}\right)}{\left(I_{11} E_{1}^{*}+I_{12} X^{*}\right)^{2}}$.

sedangkan untuk variabel adjoint $\left(\sigma_{2}^{*}\right)$ adalah

$\frac{\partial \sigma_{2}^{*}}{\partial t}=$

$-\left[H_{2}-\left(s_{1}-p_{1}\right) \frac{C_{1} E_{1}^{*} X^{*}}{\left(I_{11} E_{1}^{*}+I_{12} X^{*}\right) L}-\left(p_{2} b+2 \alpha_{2} Y^{*}\right)\right] e^{-\delta t}$

$-\sigma_{1}\left[\frac{C_{1} E_{1}^{*} X^{*}}{\left(I_{11} E_{1}^{*}+I_{12} X^{*}\right)}\right]-\sigma_{2}\left[r_{2}\left[1-\frac{2 Y^{*}}{L}\right]-\frac{C_{2} I_{21} E_{2}^{*}\left(1-\frac{X^{*}}{L}\right)}{\left(I_{12} E_{2}^{*}+I_{22} Y^{*}\right)^{2}}\right]$

dengan

$H_{2}=\left(s_{2}-p_{2}\right) \frac{C_{2} I_{21} E_{2}^{* 2}\left(1-\frac{X^{*}}{L}\right)}{\left(I_{21} E_{2}^{*}+I_{22} Y^{*}\right)^{2}}$.

Penyelesaian masalah kontrol optimal yang telah diuraikan sebelumnya dapat dinyatakan dalam Teorema 1 berikut ini.

Teorema 1. Pada masalah kontrol optimal persamaan (3) dengan kendala sistem persamaan (1) dan (2), terdapat kontrol optimal $E_{1}^{*}, E_{2}^{*}$ dan solusi state optimal $X^{*}, Y^{*}$ sedemikian sehingga nilai $J\left(E_{1}^{*}\right.$, $\left.E_{2}^{*}\right)$ maksimum. Selain itu, terdapat variabel adjoint $\sigma_{1}, \sigma_{2}$ yang memenuhi persamaan (9) dan (10) dengan kondisi transversal pada persamaan (6). Selanjutnya, kontrol optima $E_{1}^{*}, E_{2}^{*}$ diberikan oleh persamaan (17) dan (18).

Selanjutnya, solusi sistem optimal diperoleh dengan menyelesaikan persamaan (21) dan (22) dengan menggunakan metode Sweep Maju-Mundur (Lenhart dan Workman [8]). Metode Sweep Maju-Mundur merupakan metode numerik yang digunakan untuk menyelesaikan masalah kontrol optimal dengan mendiskritisasi interval $[0, T]$ di titik-titik $t_{i}=0+$ $i h, i=1,2, \ldots, n$, dengan $h$ merupakan ukuran langkah waktu dengan $t_{n}=T$. Selanjutnya, variabel $X, Y, \sigma_{1}, \sigma_{2}, E_{1}$ dan $E_{2}$ dinyatakan sebagai $X(i)$, $Y(i), \sigma_{1}(i), \sigma_{2}(i), E_{1}(i)$, dan $E_{2}(i)$. Adapun langkahlangkah algoritma metode Sweep Maju-Mundur seperti berikut ini.

Langkah 1: Membuat dugaan awal nilai $E_{1}$ dan $E_{2}$ Langkah 2: Menggunakan kondisi awal $X(0)=$ $X_{0}, Y(0)=Y_{0}$ dan nilai awal $E_{1}$ dan $E_{2}$ untuk menyelesaikan persamaan state $X$ dan $Y$ dengan langkah maju metode Runge-Kutta orde 4.

Langkah 3: Menggunakan kondisi transversal $\sigma_{1}\left(t_{\text {end }}\right)=\sigma_{2}\left(t_{\text {end }}\right)=0$ dan nilai
$X, Y, \sigma_{1}, \sigma_{2}, E_{1}$ dan $E_{2}$ untuk menyelesaikan persamaan costate dengan langkah mundur metode Runge-Kutta orde.

Langkah 4: Memperbarui nilai kontrol $E_{1}$ dan $E_{2}$ dengan memasukkan nilai $X, Y, \sigma_{1}$ dan $\sigma_{2}$ ke dalam persamaan karakteristik dari $E_{1}$ dan $E_{2}$.

Langkah 5: Memeriksa konvergensi. Jika nilai error setiap variabel dalam iterasi saat ini dan iterasi sebelumnya kurang dari $10^{-3}$ maka nilai-nilai saat ini merupakan solusi. Sebaliknya, jika nilai errornya lebih dari $10^{-3}$ maka kembali ke Langkah 2.

\section{Hasil dan Pembahasan}

Untuk mengetahui pengaruh kontrol yang dilakukan terhadap model yang dikaji, dilakukan simulasi numerik dengan menggunakan nilai awal $X_{0}=21$ $\operatorname{dan} Y_{0}=22$. Nilai parameter yang digunakan seperti diberikan di Tabel 1. Beberapa nilai parameter yang digunakan untuk simulasi pada artikel ini disarikan dari Sana[10] dan parameter lainnya ditentukan secara random.

Untuk simulasi I, laju intrinsik pengadaan barang 1 $\left(r_{1}\right)$ dan barang $2\left(r_{2}\right)$ yang digunakan masingmasing sebesar $r_{1}=1$ dan $r_{2}=2$, sedangkan koefisien tingkat permintaan barang $1\left(C_{1}\right)$ dan tingkat permintaan barang $2\left(C_{2}\right)$ bernilai sama sebesar 0,6 . Total kapasitas gudang maksimum untuk barang 1 dan barang 2 masing-masing 50. Pengaruh laju intrinsik pengadaan barang 1 dan laju intrinsik pengadaan barang 2, tanpa kontrol dan dengan kontrol ditunjukkan pada Gambar 1 dan Gambar 2. Untuk sistem tanpa dan dengan kontrol, persediaan barang 1 meningkat sampai batas waktu tertentu dan persediaan barang 2 meningkat kemudian berhenti pada saat kapasitas gudang untuk barang 2 sudah mencapai maksimum. Berdasarkan kedua gambar terlihat juga bahwa peningkatan persediaan barang 1 lebih kecil dibandingkan peningkatan persediaan barang 2. Hal ini dikarenakan laju intrinsik pengadaan barang 1 lebih kecil daripada laju intrinsik pengadaan barang 2. Untuk sistem dengan kontrol, yaitu dengan $E_{1 \max }=E_{2 \max }=1$, dan $E_{1 \text { max }}=E_{2 \text { max }}=9$, Gambar 1 dan Gambar 2 menunjukkan bahwa semakin besar usaha tim penjualan, maka persediaan barang semakin sedikit, bahkan hampir habis sampai batas waktu yang ditentukan.

Tabel 1. Nilai parameter untuk simulasi numerik

\begin{tabular}{lccccccccc}
\hline Nilai & $L_{1}$ & $L_{2}$ & $L$ & $I_{11}$ & $I_{12}$ & $I_{21}$ & $I_{22}$ & $p_{1}$ & $p_{2}$ \\
parameter & 50 & 50 & 100 & 0,6 & 0,4 & 0,5 & 0,3 & 16 & 8 \\
\hline Nilai & $\alpha_{1}$ & $\alpha_{2}$ & $\gamma_{1}$ & $\gamma_{2}$ & $S_{1}$ & $S_{2}$ & $\delta$ & $b$ & \\
parameter & 0,01 & 0,01 & 5 & 7 & 26 & 20 & 0,05 & 0,11 & \\
\hline
\end{tabular}




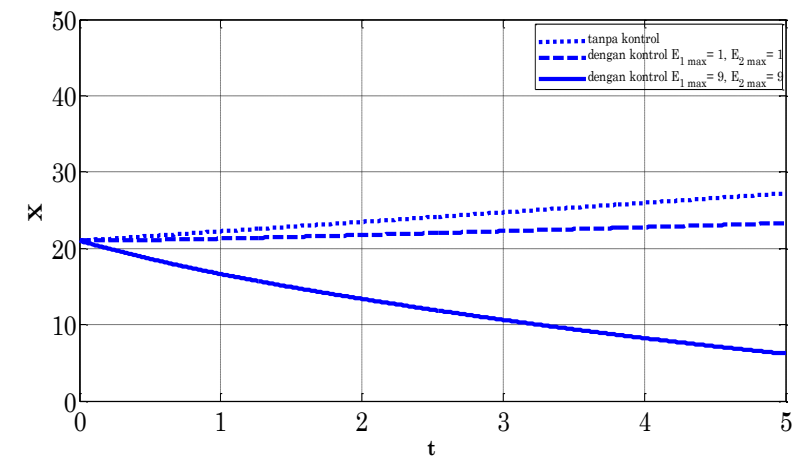

Gambar 1. Hasil persediaan barang 1 dengan $r_{1}=0,1 ; C_{1}$ $=0,6 ; r_{2}=2 ; C_{2}=0,6$ tanpa kontrol dan dengan kontrol $E_{1 \text { max }}=1 ; E_{1 \text { max }}=9 ; E_{2 \text { max }}=1 ; E_{2 \text { max }}=9$.

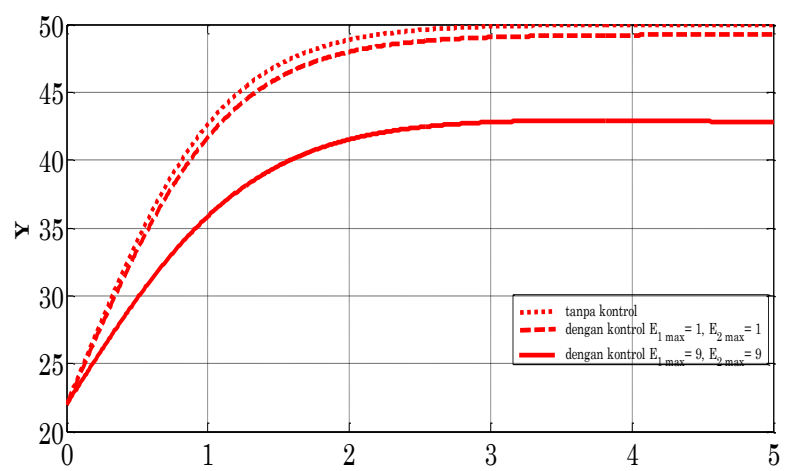

Gambar 2. Hasil persediaan barang 2 dengan $r_{1}=0,1 ; C_{1}$ $=0,6 ; r_{2}=2 ; C_{2}=0,6$; tanpa kontrol dan dengan kontrol $E_{1 \text { max }}=1 ; E_{1 \text { max }}=9 ; E_{2 \text { max }}=1 ; E_{2 \max }=9$.

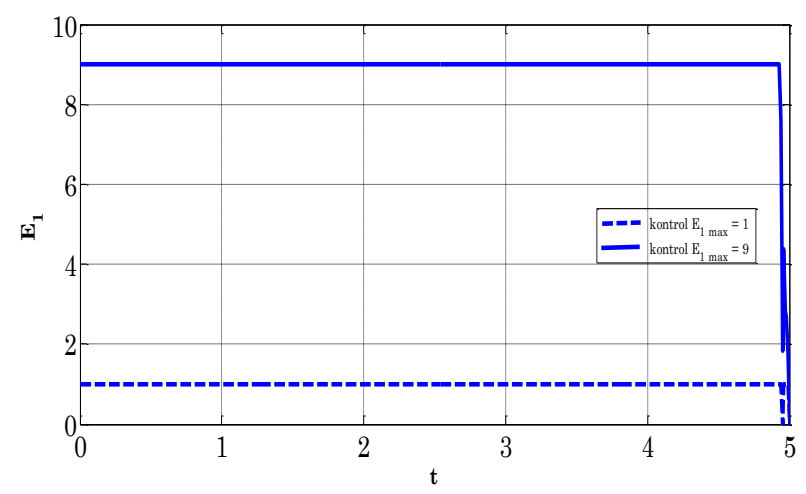

Gambar 3. Kontrol optimal $E_{1}$ terhadap model dengan $r_{1}$ $=0,1 ; C_{1}=0,6 ; r_{2}=2 ; C_{2}=0,6$.

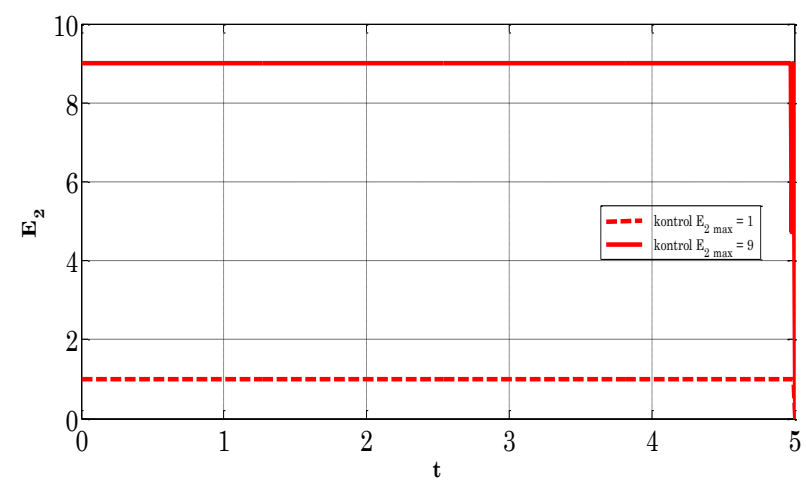

Gambar 4. Kontrol optimal $E_{2}$ terhadap model dengan $r_{1}$ $=0,1 ; C_{1}=0,6 ; r_{2}=2, C_{2}=0,6$.
Gambar 3 dan Gambar 4 menunjukkan kontrol optimal $E_{1}$ dan $E_{2}$. Pada Gambar 3 terlihat bahwa kontrol $E_{1}$ yang dilakukan pada awal periode adalah maksimum, kemudian pada sebelum akhir periode sudah mengalami penurunan hingga mencapai minimum di akhir periode. Pada Gambar 4, kontrol $E_{2}$ yang dilakukan selalu maksimum dari awal hingga akhir periode. Hal ini menunjukkan bahwa tim penjualan harus berusaha maksimal dari awal sampai batas waktu yang ditentukan. Berdasarkan Gambar 3, tim penjualan dapat mulai menghentikan usahanya sebelum batas waktu akhir. Hal ini dapat terjadi dikarenakan laju intrinsik pengadaan barang 1 relatif kecil dibandingkan laju intrinsik pengadaan barang 2 , sehingga persediaan barang 1 lebih cepat habis daripada barang 2 habis.

Untuk simulasi II ini, digunakan laju intrinsik pengadaan barang $1\left(r_{1}\right)$ adalah 1,2 dan koefisien positif tingkat permintaan barang $1\left(C_{1}\right)$ adalah 0,6. Sedangkan laju intrinsik pengadaan barang $2\left(r_{2}\right)$ adalah 2 dan koefisien positif tingkat permintaan barang $2\left(C_{2}\right)$ adalah 0,6. Hasil simulasi numerik seperti ditunjukkan pada Gambar 5 dan Gambar 6. Berdasarkan kedua gambar tersebut, untuk sistem yang tanpa kontrol maupun dengan kontrol terlihat bahwa persediaan kedua barang akan berhenti pada saat kapasitas gudang untuk kedua barang maksimum. Persediaan barang 1 (Gambar 5) lebih cepat mencapai kapasitas maksimum gudang dibandingkan hasil dari simulasi I (Gambar 1) dikarenakan laju intrinsik pengadaan barang 1 yang digunakan relatif lebih tinggi daripada di simulasi I. Dalam hal ini, pengontrolan $E_{1}$ dan $E_{2}$ yang dilakukan selalu maksimum dari awal hingga akhir waktu, yaitu $E_{1 \text { max }}=E_{2 \max }=1$, dan $E_{1 \text { max }}=E_{2 \max }=9$, seperti ditunjukkan pada Gambar 7 dan Gambar 8.

Pada simulasi III, nilai parameter yang digunakan sama seperti pada simulasi II, tetapi koefisien tingkat permintaan barang 1 sebesar $C_{1}=2$ dan koefisien tingkat permintaan barang 2 sebesar $C_{2}=$ 5. Hasil simulasi seperti ditunjukkan pada Gambar 9 dan Gambar 10 menunjukkan bahwa adanya perubahan yang signifikan dari tingkat permintaan kedua barang, berakibat pada persediaan barang baik untuk sistem yang tanpa kontrol maupun dengan kontrol. Akan tetapi, dari kedua gambar tersebut dapat dilihat bahwa persediaan barang 1 dan barang 2 untuk sistem dengan kontrol selalu lebih sedikit daripada sistem yang tanpa kontrol. Proses persediaan barang 1 dan persediaan barang 2 akan meningkat dan berhenti pada saat kapasitas gudang barang 1 dan kapasitas gudang barang 2 dalam kondisi maksimum. Lebih lanjut, adanya kontrol yang berbentuk usaha tim penjualan sangat berpengaruh terhadap persediaan barang ini. 


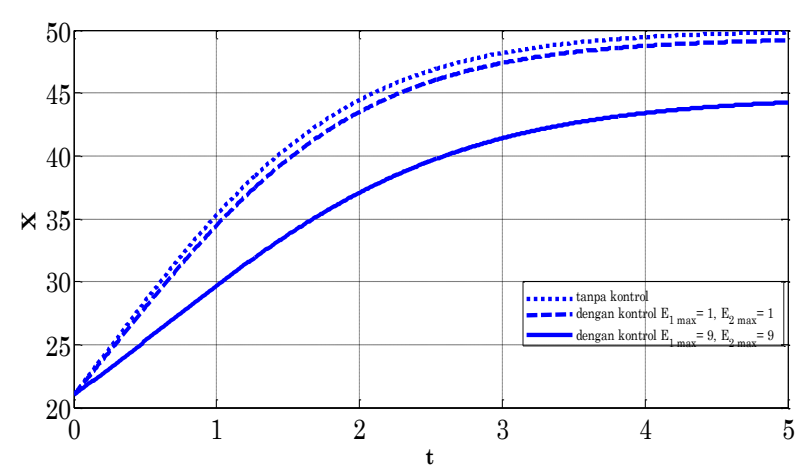

Gambar 5. Hasil persediaan barang 1 dengan $r_{1}=1,2 ; C_{1}$ $=0,6 ; r_{2}=2 ; C_{2}=0,6$ tanpa kontrol dan dengan kontrol $E_{1 \text { max }}=1 ; E_{1 \text { max }}=9 ; E_{2 \text { max }}=1 ; E_{2 \text { max }}=9$

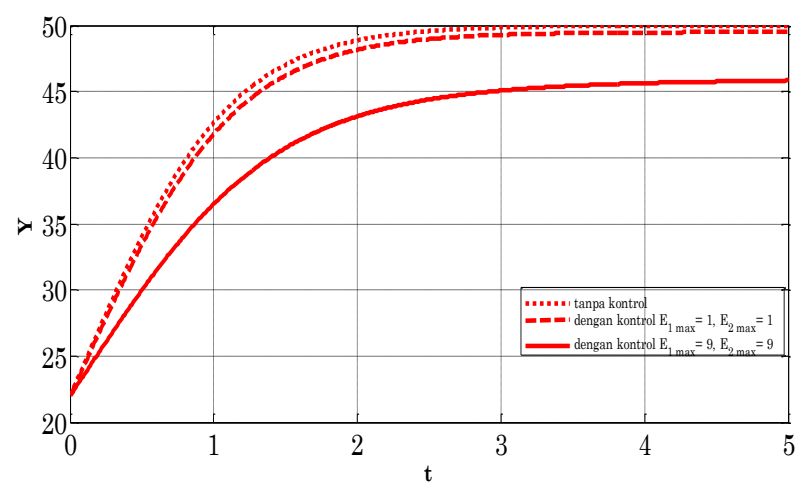

Gambar 6. Hasil persediaan barang 2 dengan $r_{1}=1,2 ; C_{1}$ $=0,6 ; r_{2}=2 ; C_{2}=0,6$ tanpa kontrol dan dengan kontrol $E_{1 \text { max }}=1 ; E_{1 \text { max }}=9 ; E_{2 \text { max }}=1 ; E_{2 \text { max }}=9$

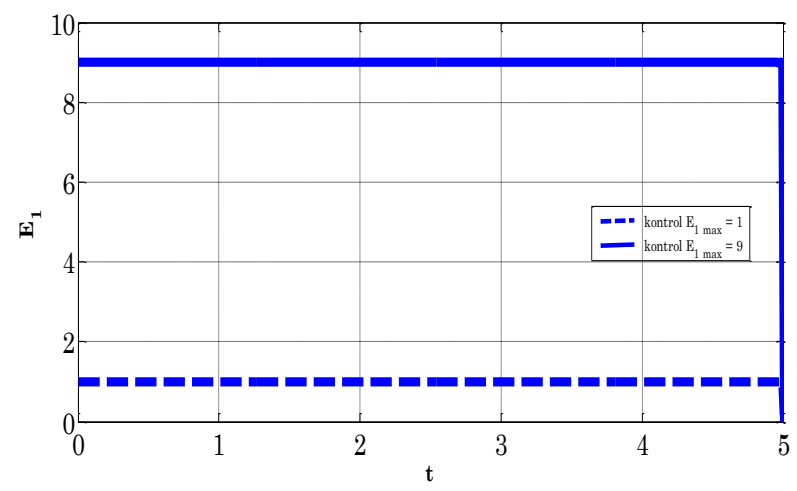

Gambar 7. Kontrol optimal $E_{1}$ terhadap model dengan $r_{1}$ $=1,2 ; C_{1}=0,6 ; r_{2}=2 ; C_{2}=0,6$

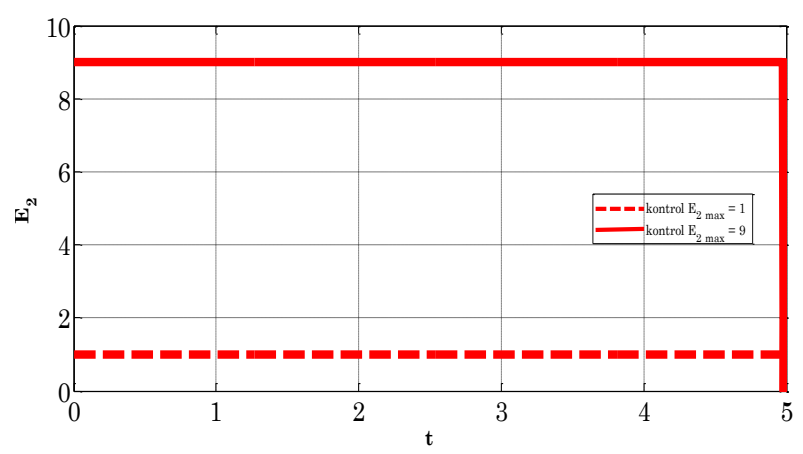

Gambar 8. Kontrol optimal $E_{2}$ terhadap model dengan $r_{1}$ $=1,2 ; C_{1}=0,6 ; r_{2}=2 ; C_{2}=0,6$
Semakin besar usaha tim penjualan, semakin cepat berkurang persedian barang. Hal ini sangat jelas ditunjukkan pada Gambar 10, dimana persedian barang 2 lebih cepat habis, diakibatkan kontrol maksimum yang dilakukan relatif jauh lebih besar (yaitu $E_{1 \max }=E_{2 \max }=1$, dan $E_{1 \max }=E_{2 \max }=9$ ). Dalam hal ini, disamping diakibatkan kontrol yang dilakukan juga dapat dikarenakan pengaruh koefisien positif permintaan barang $2 \quad\left(C_{2}=5\right)$ yang relatif lebih besar dibandingkan koefisien permintaan barang $1\left(C_{1}=2\right)$.

Gambar 11 dan Gambar 12 menunjukkan kontrol optimal $E_{1}$ dan $E_{2}$ untuk simulasi III. Berdasarkan Gambar 11, dapat diketahui pengontrolan dilakukan setiap saat dengan kontrol maksimum $E_{1 \text { max }}=$ $1, E_{1 \max }=9$, mulai awal hingga akhir waktu pengontrolan yang ditentukan. Pada Gambar 12 terlihat bahwa kontrol $E_{2}$ yang dilakukan pada awal periode adalah maksimum $\left(E_{2 \max }=1, E_{2 \max }=9\right)$, kemudian pada sebelum akhir periode sudah mengalami penurunan hingga mencapai minimum. Hal ini menunjukkan bahwa tim penjualan harus berusaha maksimal sampai batas waktu yang ditentukan dan dapat mulai berhenti usahanya sebelum batas waktu akhir.

Berdasarkan hasil yang sudah diuraikan sebelumnya termasuk hasil-hasil simulasi numerik yang diberikan pada Gambar (1) - (12), dapat diketahui bahwa kontrol optimal inisiatif tim penjualan dengan memperhatikan laba bersih maksimum yang dilakukan pada penelitian ini sifatnya tidak konstan, dalam artian bahwa kontrol yang berupa inisiatif tim penjualan dapat diketahui perubahannya setiap saat dari waktu ke waktu selama periode penjualan. Pengaruh kontrol yang dilakukan terhadap jumlah persediaan barang yang ada dengan koefisien tingkat permintaan barang yang berbeda juga dapat diketahui dari waktu ke waktu (untuk barang 1 dan barang 2). Hal ini merupakan kontribusi utama dari penelitian ini yang membedakan dengan Sana [11], dimana pada penelitian Sana [11] kontrol hanya dilakukan pada keadaan setimbang (kondisi stabil), dalam artian bahwa kontrol yang dilakukan bersifat konstan atau tetap. Dengan demikian, berdasarkan penyelesaian kontrol optimal terhadap model pengendalian persediaan yang dikaji dalam penelitian ini, pada kondisi yang sesuai, perusahaan akan dapat selalu memonitor usaha yang dilakukan oleh tim penjualan setiap saat, apakah sudah maksimum atau tidak selama periode waktu yang telah ditentukan dari waktu ke waktu, termasuk kesesuaian usaha yang dilakukan terhadap jumlah persediaan barang yang ada. Hal ini tentu akan memudahkan pimpinan perusahaan di dalam memonitor usaha tim penjualan di dalam melakukan penjualan barang. 


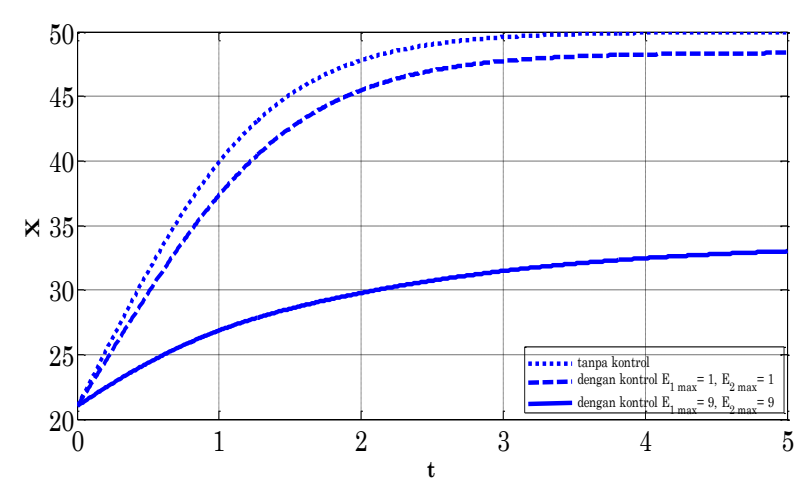

Gambar 9. Hasil persediaan barang 1 dengan $r_{1}=1,2 ; C_{1}$ $=2 ; r_{2}=2 ; C_{2}=5$ tanpa kontrol dan dengan kontrol $E_{1}$ max $=1 ; E_{1 \text { max }}=9 ; E_{2 \text { max }}=1 ; E_{2 \max }=9$

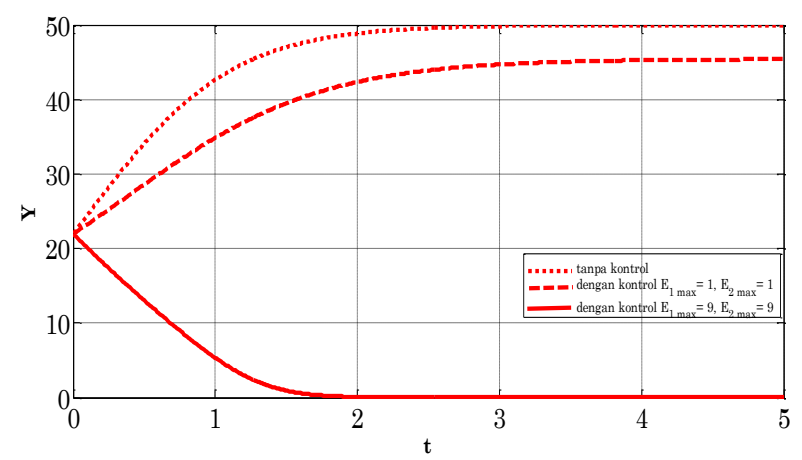

Gambar 10. Hasil persediaan barang 2 dengan $r_{1}=1,2 ; C_{1}$ $=2 ; r_{2}=2 ; C_{2}=5$ tanpa kontrol dan dengan kontrol $E_{1 \text { max }}$ $=1 ; E_{1 \text { max }}=9 ; E_{2 \text { max }}=1 ; E_{2 \text { max }}=9$

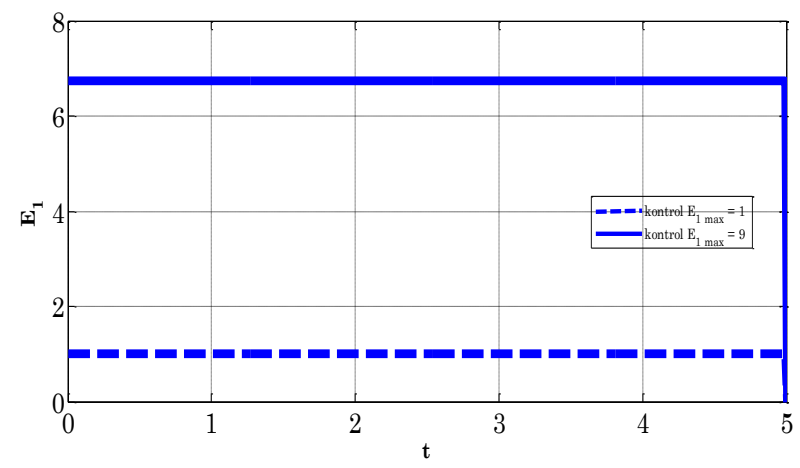

Gambar 11. Kontrol optimal untuk $E_{1}$ terhadap model dengan $r_{1}=1,2 ; C_{1}=2 ; r_{2}=2 ; C_{2}=5$

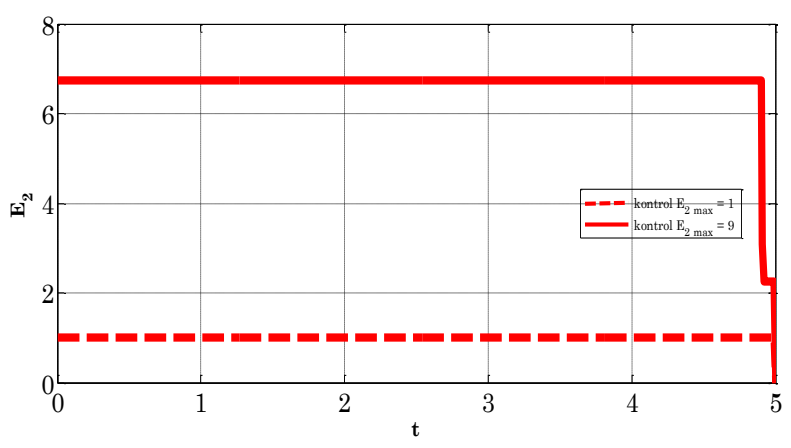

Gambar 12. Kontrol optimal untuk $E_{2}$ terhadap model dengan $r_{1}=1,2 ; C_{1}=2 ; r_{2}=2 ; C_{2}=5$

\section{Simpulan}

Telah didapatkan penyelesaian masalah kontrol optimal pada model EOQ dengan inisiatif tim penjualan tidak hanya pada saat kondisi setimbang saja, tetapi kontrol optimal dengan usaha tim penjualan pada setiap saat. Strategi kontrol optimal dilakukan dengan meminimumkan biaya persediaan, biaya pembelian, biaya penjualan dan biaya usaha tim penjualan. Berdasarkan hasil simulasi numerik diketahui bahwa semakin besar koefisien tingkat permintaan barang 1 dan koefisien tingkat permintaan barang 2, maka persediaan barang 1 dan persediaan barang 2 akan lebih cepat berkurang. Semakin besar usaha tim penjualan, maka proses persediaan barang juga lebih sedikit bahkan lebih cepat habis. Dalam hal ini pengaruh kontrol berupa inisiatif tim penjualan terhadap jumlah persediaan barang dapat diketahui dari waktu ke waktu, sehingga perusahaan selalu dapat memonitor usaha yang dilakukan oleh tim penjualan setiap saat, apakah sudah maksimum atau tidak selama periode waktu yang telah ditentukan dari waktu ke waktu, termasuk kesesuaian usaha yang dilakukan terhadap jumlah persediaan barang yang ada.

\section{Daftar Pustaka}

1. Dhaiban, A.K., Comparison between Linear Programming Model and Optimal Control Model of Production-Inventory System, Current Science, 112(9), 2017, pp. 1855-1863.

2. Kostic, K., Inventory Control as a Discrete System Control for the Fixed-Order Quantity System, Applied Mathematical Modelling, 33, 2009, pp. 4201-4212.

3. Muckstadt, J.A. and Sapara, A., Principles of Inventory Management: When You are Down to Four, Order More. Springer Series in Operation Research and Financial Engineering, 2010.

4. Baker, R.C. and Urban, T.L., A Deterministic Inventory System with Inventory-Level-Dependent Demand Rate, Journal of the Operation Research Society, 39, 1988, pp. 823-831.

5. Datta, T.K. and Pal, A.K., Deterministic Inventory System for Deteriorating Items with Inventory Level Dependent Demand Rate and Storages, Opsearch, 27, 1990, pp. 213-224.

6. Ghosh S.K. and Chaudhuri, K.S., An Order Level Inventory Model for a Deteriorating Item with Two Levels of Storage Stock-Dependent Demand, Far East Journal of Applied Matematics, 15, 2004, pp. 63-77.

7. Husniah, H. dan Supriatna, A.K., Model Dinamis Persediaan Tiga Produk dengan Penjualan Bersama, Jurnal Industrial Services, 1(1), 2015, pp. 1-6. 
8. Lenhart, S. and Workman, J., Optimal Control Applied to Biological Models, Chapman and Hall/ CRC, London, 2007.

9. Sana, S.S., An EOQ Model of Homogeneous Products while Demand is Salesmen's Initiatives and Stock Sensitive, Computers and Mathematics with Applications, 62, 2011, pp. 577-578.

10. Sana, S.S., An EOQ Model for Salesman's Initiatives, Stock, and Price Sensitive Demand of Similar Products-A Dynamical System, Applied
Mathematics and Computation, 218, 2011, pp. 3277-3288.

11. Sana, S.S., The EOQ Model - A Dynamical System, Applied Mathematics and Computation, 218, 2012, pp. 8736-8749.

12. Anggriani, N., Lesmana, E., Supriatna, A., Husniah, H., dan Yudha, M., Analisis Dinamik pada Model Pengendalian Persediaan Dua Produk berbeda, Jurnal Teknik Industri, 17, 2015, pp. 17-26. 